\title{
Pathogenicity testing of shellfish hatchery bacterial isolates on Pacific oyster Crassostrea gigas larvae
}

\author{
Robyn M. Estes ${ }^{1}$, Carolyn S. Friedman ${ }^{1}$, Ralph A. Elston ${ }^{2}$, Russell P. Herwig ${ }^{1, *}$ \\ ${ }^{1}$ School of Aquatic and Fishery Sciences, University of Washington, PO Box 355020, Seattle, Washington 98195, USA \\ ${ }^{2}$ AquaTechnics and Pacific Shellfish Institute, PO Box 687, Carlsborg, Washington 98324, USA
}

\begin{abstract}
Bacterial diseases are a major cause of larval mortality in shellfish hatcheries. Even with proper sanitation measures, bacterial pathogens cannot be eliminated in all cases. The pathogenicity of bacteria isolated from Pacific Northwest shellfish hatcheries to Pacific oyster Crassostrea gigas larvae was investigated. We found 3 highly pathogenic strains and 1 mildly pathogenic strain among 33 isolates tested. These strains appear to be members of the genus Vibrio. Although there have been many studies of bivalve bacterial pathogens, a standard method to assess bacterial pathogenicity in bivalve larvae is needed. Thus, we developed 2 methods using either $15 \mathrm{ml}$ conical tubes or tissue culture plates that were employed for rapidly screening bacterial strains for pathogenicity to Pacific oyster larvae. The tissue culture plates worked well for screening both mildly pathogenic strains and $\mathrm{LD}_{50}$ (lethal dose) assays. This method allowed for non-intrusive and non-destructive observation of the oyster larvae with a dissecting microscope. The $\mathrm{LD}_{50}$ for the 3 highly pathogenic strains ranged between 1.6 and $3.6 \times 10^{4}$ colony forming units $(\mathrm{CFU}) \mathrm{ml}^{-1}$ after $24 \mathrm{~h}$ and between $3.2 \times 10^{2}$ and $1.9 \times$ $10^{3} \mathrm{CFU} \mathrm{ml}{ }^{-1}$ after $48 \mathrm{~h}$.
\end{abstract}

KEY WORDS: Pacific oyster larvae $\cdot$ Vibrio $\cdot$ Bacteria $\cdot$ Pathogenicity testing $\cdot$ Shellfish hatchery Resale or republication not permitted without written consent of the publisher

\section{INTRODUCTION}

Bacterial diseases are a major cause of mortality in the culture of molluscan bivalve larvae. Mortality often results from infection with pathogenic bacteria (Brown 1981, Elston et al. 1981, Elston 1984, 1999, Lodeiros et al. 1987, Riquelme et al. 1996). Outbreaks can result in major losses and great expense for shellfish growers. Even with proper sanitation measures, disease outbreaks caused by pathogens or opportunistic bacterial infections still occur in shellfish hatcheries (Elston 1984, 1999, Lodeiros et al. 1987, Sugumar et al. 1998).

Members of the genus Vibrio are the most frequent cause of these mortalities. Bacterial strains from other genera, such as Pseudomonas, have also demonstrated pathogenicity in larval bivalves (Brown 1973, Lodeiros et al. 1987). Tubiash et al. $(1965,1970)$ first described different Vibrio strains as the causative agents for a disease they termed bacillary necrosis in larval and juvenile bivalves from a shellfish hatchery and nursery. Clinical signs included bacteria swarming around the velum, necrotic soft tissues, and detached vela, accompanied by a high mortality rate. Similar clinical signs were described in different molluscan species including hard clams Mercenaria mercenaria, eastern oysters Crassostrea virginica, European flat oysters Ostrea edulis, bay scallops Aequipectin irradians, and shipworms Teredo navalis (Tubiash et al. 1965).

Isolating and characterizing pathogenic bacteria is essential for understanding and managing bacterial diseases in shellfish hatcheries. Many bacteria are typically isolated from apparently healthy or moribund shellfish larvae. Thus, it is essential to be able to distinguish pathogenic from non-pathogenic strains. However, no standard pathogenicity bioassay for shellfish larvae has been adopted. Oftentimes, a shellfish pathologist or microbiologist may want to screen a large number of bacterial isolates to determine which isolates may be the causative agent for a disease outbreak. The purpose of this study was to: (1) develop a method for determining the pathogenicity of a large number of bacterial isolates, and (2) assess the patho- 
genicity of bacteria isolated from bivalve hatcheries during routine monitoring and disease outbreaks.

\section{MATERIALS AND METHODS}

Isolates and reference strains. Bacterial isolates collected from Pacific oyster Crassostrea gigas larvae ( $\mathrm{n}=$ 16) and juveniles $(n=12)$, European flat oyster Ostrea edulis juveniles $(\mathrm{n}=1)$, and hatchery environments ( $\mathrm{n}=4$ ) from the Pacific Northwest of the United States (Table 1) were stored at $-80^{\circ} \mathrm{C}$ in Marine 2216 broth (Difco Laboratories) with $10 \%$ (v/v) glycerol. Subsequently, they were shipped on dry ice from AquaTechnics (Sequim) to the University of Washington (Seattle, Washington). The following control strains were included in the pathogenicity assays: RE 14 (nonpathogenic or negative control), RE 82 (pathogenic or positive control), and previously described larval bivalve pathogens Vibrio alginolyticus American Type Culture Collection (ATCC) 19108 and V. tubiashii ATCC 19106 (Tubiash et al. 1965, 1970). All cultures were maintained at $-80^{\circ} \mathrm{C}$ for long-term storage.

Isolates were grown for $24 \mathrm{~h}$ on Marine 2216 agar and incubated at 20 and $26^{\circ} \mathrm{C}$ in the first and second set of experiments, respectively. Experiments were conducted using sand-filtered Puget Sound seawater collected at the Seattle Aquarium (Seattle, Washington). Suspensions of the bacterial strains in filter-sterilized $(0.22 \mu \mathrm{m})$ seawater were adjusted to an optical density $(600 \mathrm{~nm})$ of 0.2 to attain a uniform concentration of bacteria for the experiments. Bacterial density was confirmed by standard plate-count assays using Marine 2216 agar.

Pathogenicity testing. Experiments were performed using Pacific oyster larvae (age 10 to $12 \mathrm{~d}$ ) that were supplied by Coast Seafoods Co. (Quilcene) and shipped overnight on ice to the University of Washington. Pathogenicity testing on 6 different lots of oyster larvae was repeatedly performed over several weeks. Control batches of larvae from each lot were also held in the laboratory during each experimental period to ensure that the larvae did not already contain pathogens. Two pathogenicity assay methods were developed as described below.

Tissue culture plate assay: Bacterial isolates and control strains were tested for pathogenicity in triplicate in 12-well tissue culture plates (Corning). A different tissue culture plate was used for each isolate to avoid cross-contamination. Oyster larvae were added to each well of the tissue culture plate at a concentration of 8 to 12 larvae $\mathrm{ml}^{-1}$ and challenged with approximately $6.0 \pm 0.8 \times 10^{5}$ colony forming units (CFU) ml $\mathrm{ml}^{-1}$ of the bacterial isolate in $4 \mathrm{ml}$ of $0.22 \mu \mathrm{m}$-filter sterilized seawater. Plates were incubated for $48 \mathrm{~h}$ in the dark at 20 and $26^{\circ} \mathrm{C}$ in the first and second set of experiments, respectively. The proportion of live and dead larvae was determined at 24 and $48 \mathrm{~h}$ with the aid of a dissecting microscope. Larvae were considered dead when no movement was observed within the valves. The assay was repeated for bacterial isolates that killed larvae within $48 \mathrm{~h}$.

Conical tube assay: In the second pathogenicity assay, larvae and bacterial isolates were suspended in $15 \mathrm{ml}$ sterile, disposable plastic conical tubes (Sarstedt). Preliminary observations showed that larvae inoculated with pathogenic isolates often remained alive but developed deformities, stopped swimming, or closed their valves. Considering this observation, we performed the conical tube assay along with the tissueculture plate assay to determine whether pathogenic isolates caused the larvae to cease swimming, sink in the water column, and accumulate at the bottom of the tube. Pacific oyster larvae were added to $15 \mathrm{ml}$ conical tubes at a concentration of 16 to 32 larvae $\mathrm{ml}^{-1}$ and challenged with approximately $6.0 \pm 0.8 \times 10^{6} \mathrm{CFU}$ $\mathrm{ml}^{-1}$ of the bacterial isolate in $10 \mathrm{ml}$ of filter-sterilized seawater. Conical tubes were incubated in the dark at 20 and $26^{\circ} \mathrm{C}$ in the first and second set of experiments, respectively. The number of larvae in the top $3 \mathrm{ml}$ of the water column was enumerated after 24 and $48 \mathrm{~h}$ of incubation. Due to larvae motility, the exact number of larvae in the top $3 \mathrm{ml}$ was difficult to determine when more than 20 were present.

$\boldsymbol{L D}_{50}$ (lethal dose) assay: Pacific oyster larvae (all from the same batch) and the 4 isolates identified as pathogenic for Pacific oyster larvae from the trials described above were placed in sterile 12-well plastic disposable tissue culture plates. A separate culture plate was used for each isolate and bacterial concentration to avoid cross-contamination of the isolates. Aliquots of larvae $\left(10 \mathrm{ml}^{-1}\right)$ were added to each well (4 ml total). Bacteria were added to the wells at the approximate final concentrations of $4.4 \pm 0.9 \times 10^{2}$, $4.4 \pm 0.9 \times 10^{3}, 4.4 \pm 0.9 \times 10^{4}$, and $4.4 \pm 0.9 \times 10^{5}$ CFU ml $\mathrm{ml}^{-1}$. Six wells per plate were used for each tested isolate at the 4 bacterial concentrations. With the aid of a dissecting microscope, the numbers of live and dead larvae were determined at 24,48, and $72 \mathrm{~h}$ following inoculation. Larvae were also challenged with filtered seawater and a non-pathogenic strain (RE 14) at a concentration of approximately $10^{4}$ $\mathrm{CFU} \mathrm{ml} \mathrm{m}^{-1}$ as negative controls. Plates in which little or no mortality was observed were incubated for an additional $24 \mathrm{~h}$. The virulence of the pathogens was estimated by determining the $50 \%$ lethal dose $\left(\mathrm{LD}_{50}\right)$ (Reed \& Muench 1938). One-way ANOVA was used to compare larval survival after challenges with the 3 most virulent strains at each bacterial concentration after 24 and $48 \mathrm{~h}$. 
Table 1. Bacterial isolates associated with Pacific oysters Crassostrea gigas from the states of Washington and Oregon in the Pacific Northwest (PNW). Reference strains are included at the bottom

\begin{tabular}{|c|c|c|c|c|c|}
\hline \multirow{2}{*}{$\begin{array}{l}\text { Source } \\
\text { Pacific oyster larvae } \\
\text { (PNW) }\end{array}$} & \multicolumn{5}{|l|}{ Strains } \\
\hline & $\begin{array}{l}\text { RE } 4 \\
\text { RE } 19 \\
\text { RE } 33 \\
\text { RE } 101\end{array}$ & $\begin{array}{l}\text { RE } 8 \\
\text { RE } 21 \\
\text { RE } 39\end{array}$ & $\begin{array}{l}\text { RE } 9 \\
\text { RE } 22 \\
\text { RE } 98\end{array}$ & $\begin{array}{l}\text { RE } 10 \\
\text { RE } 30 \\
\text { RE } 99\end{array}$ & $\begin{array}{l}\text { RE } 14 \\
\text { RE } 31 \\
\text { RE } 100\end{array}$ \\
\hline $\begin{array}{l}\text { Pacific oyster seed } \\
\text { (PNW) }\end{array}$ & $\begin{array}{l}\text { RE } 7 \\
\text { RE } 20 \\
\text { RE } 61\end{array}$ & $\begin{array}{l}\text { RE } 11 \\
\text { RE } 23 \\
\text { RE } 62\end{array}$ & $\begin{array}{l}\text { RE } 13 \\
\text { RE } 28\end{array}$ & $\begin{array}{l}\text { RE } 15 \\
\text { RE } 59\end{array}$ & $\begin{array}{l}\text { RE } 16 \\
\text { RE } 60\end{array}$ \\
\hline $\begin{array}{l}\text { Flat oyster Ostrea edulis seed } \\
\text { (PNW) }\end{array}$ & RE 63 & & & & \\
\hline $\begin{array}{l}\text { Hatchery environment } \\
\text { (PNW) }\end{array}$ & RE 78 & RE 79 & RE 80 & RE 81 & \\
\hline $\begin{array}{l}\text { Pacific oyster juveniles } \\
\text { (California) }\end{array}$ & RE 82 & & & & \\
\hline Hard clam Mercenaria mercenaria seed & \multicolumn{5}{|c|}{ Vibrio alginolyticus ATCC 19108} \\
\hline Eastern oyster Crassostrea virginica seed & \multicolumn{5}{|c|}{ Vibrio tubiashii ATCC 19106} \\
\hline
\end{tabular}

Table 2. Phenotypic and growth-range properties of isolates collected from larval Pacific oysters and selected reference strains. AMCT: L-alanine-7-amido-4-methyl-coumarin trifluoroacetate; TCBS: thiosulfate citrate bile salts sucrose; O/129: 2,4-diamino6,7-diisopropyl pteridine. ATCC: American Type Culture Collection. -: negative; +: positive; G: green; Y: yellow; P: peach; O: off white $+(n)$ : positive in $n$ days; R: resistant; $\mathrm{S}$ : sensitive

\begin{tabular}{|c|c|c|c|c|c|c|c|c|c|}
\hline \multirow[b]{2}{*}{ Test } & \multicolumn{4}{|c|}{ Larval Pacific oyster isolates } & \multirow[b]{2}{*}{ 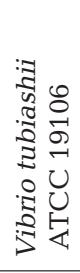 } & \multicolumn{3}{|c|}{ Reference strains } & \multirow{2}{*}{ 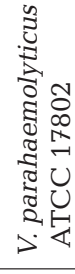 } \\
\hline & $\begin{array}{l}8 \\
\qquad \\
\simeq 1 \\
\simeq 1\end{array}$ & $\begin{array}{l}\text { N } \\
\text { 푐 }\end{array}$ & $\begin{array}{l}\infty \\
\infty \\
\widetilde{I} \\
\widetilde{\sim}\end{array}$ & $\begin{array}{l}\vec{\sigma} \\
\underset{\sim}{1} \\
\underset{1}{\sim}\end{array}$ & & 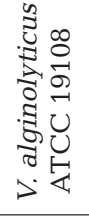 & 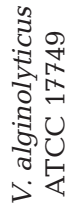 & 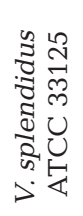 & \\
\hline Gram stain (AMCT) & - & - & - & - & - & - & - & - & - \\
\hline Oxidase & + & + & + & + & + & + & + & + & + \\
\hline Catalase & + & + & + & + & + & + & + & + & + \\
\hline \multicolumn{10}{|l|}{ Colony pigmentation: } \\
\hline TCBS agar & G & $\mathrm{Y}$ & $\mathrm{Y}$ & $\mathrm{Y}$ & $\mathrm{Y}$ & $\mathrm{Y}$ & $\mathrm{Y}$ & $\mathrm{G}$ & G \\
\hline Marine 2216 agar & $\mathrm{P}$ & $\mathrm{O}$ & $\mathrm{O}$ & $\mathrm{O}$ & $\mathrm{O}$ & $\mathrm{O}$ & $\mathrm{O}$ & $\mathrm{O}$ & $\mathrm{O}$ \\
\hline \multicolumn{10}{|c|}{ Microscopic observations: } \\
\hline Motility & + & + & + & + & + & + & + & + & + \\
\hline Morphology & Rods & Rods & Rods & Rods & Rods & Rods & Rods & Rods & Rods \\
\hline \multicolumn{10}{|l|}{ Growth temperature: } \\
\hline $4^{\circ} \mathrm{C}$ & - & - & - & - & - & - & - & - & - \\
\hline $15^{\circ} \mathrm{C}$ & $+(2)$ & + & $+(2)$ & $+(2)$ & $+(2)$ & $+(2)$ & + & $+(2)$ & $+(2)$ \\
\hline $20^{\circ} \mathrm{C}$ & + & + & + & + & + & + & + & + & + \\
\hline $30^{\circ} \mathrm{C}$ & + & + & + & + & + & + & + & + & + \\
\hline $35^{\circ} \mathrm{C}$ & - & + & + & + & + & + & + & - & + \\
\hline $40^{\circ} \mathrm{C}$ & - & - & - & - & - & - & + & - & + \\
\hline \multicolumn{10}{|l|}{ Growth in $\mathrm{NaCl}$ : } \\
\hline $0 \%$ & - & - & - & - & - & - & - & - & - \\
\hline $3 \%$ & + & + & + & + & + & + & + & + & + \\
\hline $6 \%$ & $+(6)$ & $+(2)$ & $+(3)$ & $+(3)$ & $+(4)$ & $+(4)$ & + & $+(2)$ & + \\
\hline $8 \%$ & - & - & - & - & - & - & $+(2)$ & - & $+(3)$ \\
\hline $10 \%$ & - & - & - & - & - & - & $+(3)$ & - & - \\
\hline \multicolumn{10}{|l|}{ Sensitivity: } \\
\hline $10 \mu \mathrm{g} \mathrm{O} / 129$ & $\mathrm{R}$ & $\mathrm{R}$ & $\mathrm{R}$ & $\mathrm{R}$ & $\mathrm{R}$ & $\mathrm{R}$ & $\mathrm{R}$ & $\mathrm{R}$ & $\mathrm{R}$ \\
\hline $150 \mu \mathrm{g} \mathrm{O} / 129$ & $\mathrm{~S}$ & $\mathrm{R}$ & $\mathrm{S}$ & $\mathrm{S}$ & $\mathrm{S}$ & $\mathrm{S}$ & $\mathrm{R}$ & $\mathrm{R}$ & $\mathrm{S}$ \\
\hline
\end{tabular}


Extracellular toxin production. To determine whether extracellular toxin production contributed to the pathogenicity of the bacteria identified in these studies, we challenged oyster larvae with filtrates from the 3 highly pathogenic isolates (RE 22, RE 98, RE 101). Pacific oyster larvae and bacterial isolates $\left(10^{7} \mathrm{CFU} \mathrm{ml}{ }^{-1}\right)$ were incubated overnight at $20^{\circ} \mathrm{C}$ in conical tubes at a concentration of approximately 10 larvae $\mathrm{ml}^{-1}$. Conical tubes with larvae alone and larvae with a non-pathogenic bacterium (RE 14) were also incubated as controls. After $24 \mathrm{~h}$ incubation, the larvae incubated with the 3 pathogenic isolates were dead at the bottom of the tubes. The conditioned fluid was then removed and filtered through a $25 \mathrm{~mm}$ diameter, $0.22 \mu \mathrm{m}$ syringe filter. Aliquots of 100 or $10 \%$ filtrate were then added to tissue culture plates ( 3 wells each). The number of live and dead larvae following exposure to the filtrate was determined at 24 and $48 \mathrm{~h}$ with the aid of a dissecting microscope.

Phenotypic properties of isolates. The 3 highly pathogenic isolates (RE 22, RE 98, RE 101), 1 mildly pathogenic isolate (RE 60), Vibrio alginolyticus ATCC 19108, and V. tubiashii ATCC 19106 were examined for the phenotypic properties outlined in Table 2 to provide a preliminary description of bacterial isolates (Holt et al. 1994). Three ATCC-type strains were also included in the phenotypic testing: $V$. alginolyticus ATCC 17749, $V$. splendidus ATCC 33125, and V. parahaemolyticus ATCC 17802. Oxidase and catalase production and sensitivity to the vibriostatic agent O/129 (Oxoid) were performed as previously described (Gerhardt et al. 1994). Gram-stain reactions were tested by using the method described by Manafi \& Kneifel (1990). Colony pigmentation was determined on Marine 2216 and thiosulfate citrate bile salts sucrose (TCBS) agars (Difco). Cell morphology and motility were determined by examination of the cells using phase-contrast microscopy.

Growth of the cultures at different salinities and temperatures was determined. For the salinity range of growth, cells were suspended in 3 tubes containing $1 \%$ tryptone broth agar with either $0,3,6,8$, or $10 \%$ $\mathrm{NaCl}$ and incubated at $20^{\circ} \mathrm{C}$ for up to $1 \mathrm{wk}$. To determine the temperature range of growth, cells were suspended in 3 tubes containing $\mathrm{T}_{1} \mathrm{~N}_{2}$ (1\% tryptone, $2 \%$ $\mathrm{NaCl}$ ) broth and incubated at $4,15,20,30,35$, and $40^{\circ} \mathrm{C}$ for up to $2 \mathrm{wk}$.
Pathogenicity Assay - Tissue Culture Plates

$20^{\circ} \mathrm{C}$
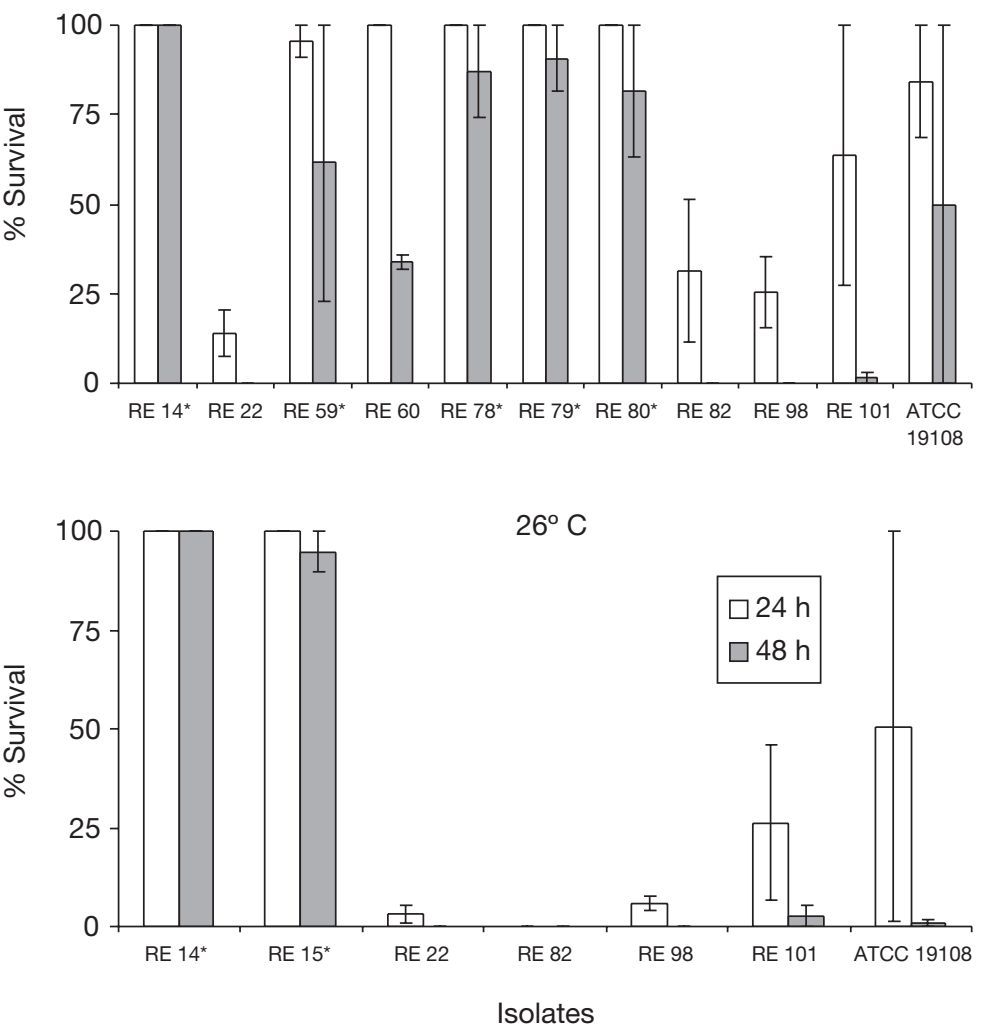

Fig. 1. Tissue culture plate assay for pathogenicity of bacterial isolates to Crassostrea gigas larvae at 20 and $26^{\circ} \mathrm{C}$. Isolates associated with $100 \%$ surare not shown. No bars are present for the isolates with $0 \%$ survival larvae. Error bar represents \pm 1.0 SE. RE 82 = positive control, pathoic strain. RE $14=$ negative control, non-pathogenic isolate. ${ }^{*}$ : strain

considered non-pathogenic. ATCC: American Type Culture Collection

\section{RESULTS}

\section{Pathogenicity testing}

Tissue culture plate assay

Of the 33 strains of bacteria isolated from bivalve larvae and shellfish hatchery environments from the Pacific Northwest (Table 1), only 3 strains (RE 22, RE 98, RE 101) were consistently pathogenic to Pacific oyster larvae with few or no larvae surviving after $48 \mathrm{~h}$ at 20 and $26^{\circ} \mathrm{C}$ (Fig. 1) in the tissue culture plate. Strain RE 60 was mildly pathogenic at $20^{\circ} \mathrm{C}$, with $33.7 \pm 2.1 \%$ survival after $48 \mathrm{~h}$, and non-pathogenic at $26^{\circ} \mathrm{C}$. Strains RE 59, RE 60, RE 78, RE 79, and RE 80 appeared mildly pathogenic in the first trial at $20^{\circ} \mathrm{C}$ but demonstrated no pathogenic effect when the experiment was repeated. No mortality was observed when these 5 strains were tested at $26^{\circ} \mathrm{C}$. No larval mortality was 

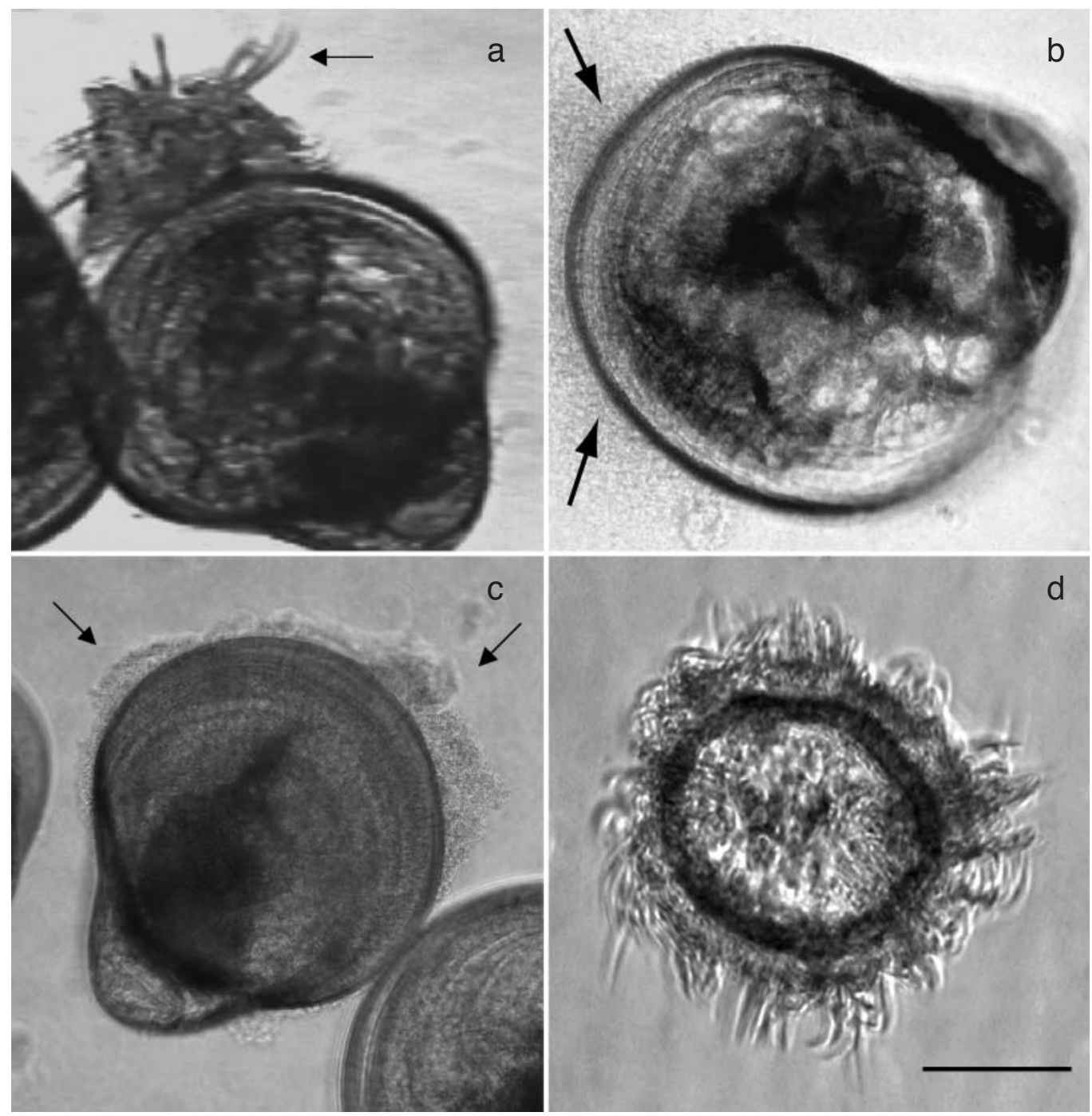

Fig. 2. Crassostrea gigas. (a) Larval Pacific oyster with protruding velum and clumped cilia (arrow) $24 \mathrm{~h}$ after inoculation with bacterial isolate RE 22. (b) Larval Pacific oyster with swarming bacteria (arrows) $24 \mathrm{~h}$ after inoculation with bacterial isolate RE 22. (c) Larval Pacific oyster with bacterial swarming and tissues protruding (arrows) outside its valves $24 \mathrm{~h}$ after inoculation with bacterial isolate RE 22. (d) Malformed larvae (detached vela) were often present in lots of otherwise healthy larval oysters.

These individuals survived longer than normal larvae after inoculation with bacterial pathogens. Scale bar $=100 \mu \mathrm{m}$

observed in challenges with the remaining 30 bacterial isolates. Vibrio tubiashii ATCC 19106 was not pathogenic under the assay conditions. $V$. alginolyticus ATCC 19108 was mildly pathogenic (84 $\pm 15.8 \%$ survival after $24 \mathrm{~h}, 50 \pm 50 \%$ survival after $48 \mathrm{~h}$ ) at $20^{\circ} \mathrm{C}$, but demonstrated greater pathogenicity (50.6 $\pm 49.4 \%$ survival after $24 \mathrm{~h}, 1.0 \pm 1.0 \%$ survival after $48 \mathrm{~h}$ ) at $26^{\circ} \mathrm{C}$.

\section{Morphology of oyster larvae in experiments}

Within 24 h of inoculation with the highly pathogenic strains (RE 22, RE 98, RE 101), a proportion of the lar- vae appeared abnormal, with a deformed velum (Fig. 2a), and exhibited circular swimming movements on their sides. The abnormal velum of these moribund larvae were stalk-like with clumped cilia. In contrast, the velum of healthy larvae extended along the edge of the valves and was covered with well-defined cilia. In our experiments, larvae were considered dead when they no longer moved. Dead larvae usually had tissues protruding from their valves and microorganisms swarmed around these individuals (Fig. 2b,c), a sign of bacillary necrosis (Brown 1973). The vela of larvae that survived challenges with the highly pathogenic strains were usually visibly deformed after $24 \mathrm{~h}$. Malformed larvae that looked like detached vela (Fig. 2d) ap- 

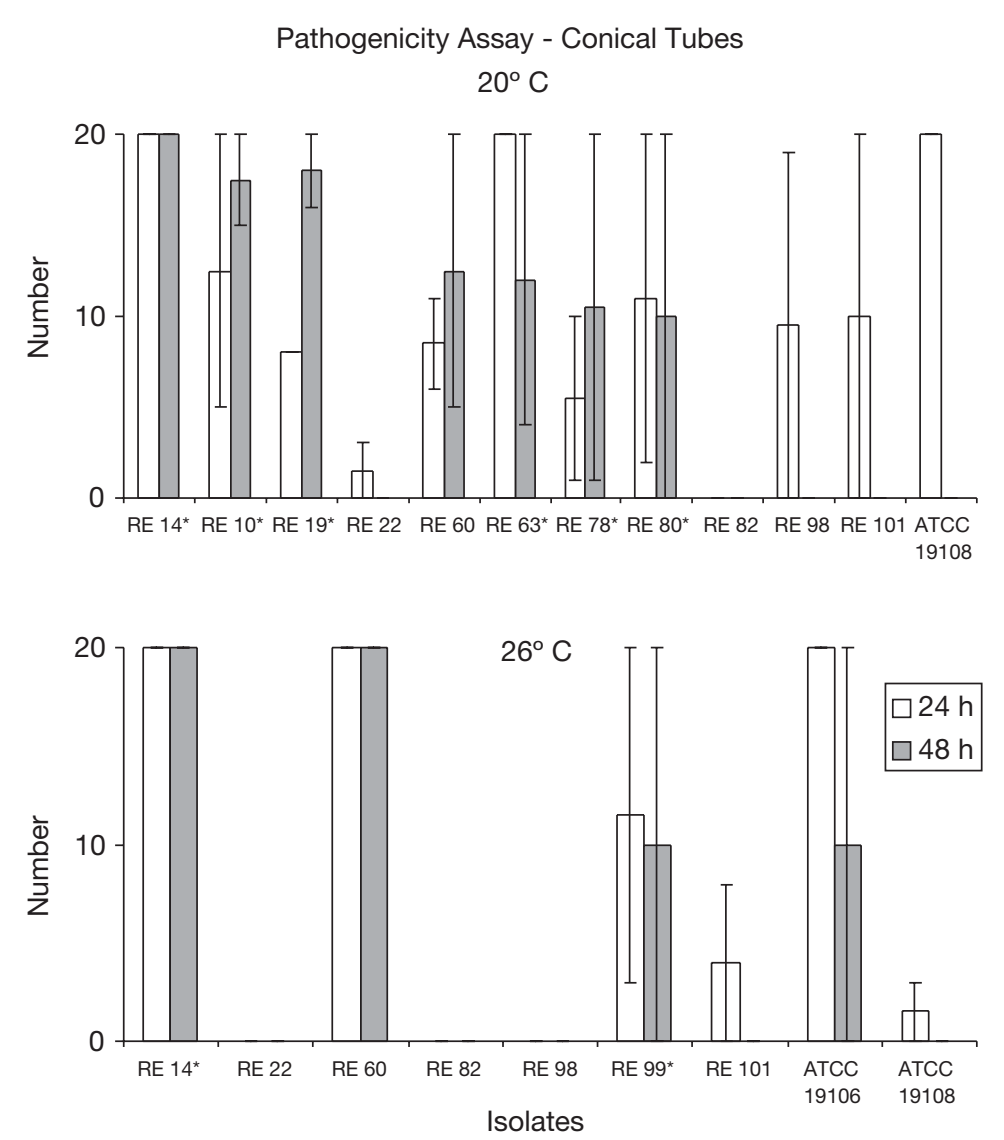

Fig. 3. Conical tube assay for pathogenicity of bacterial isolates to Crassostrea gigas larvae at $20^{\circ} \mathrm{C}$. Isolates associated with $100 \%$ survival are not shown. No bars are present for isolates with no larvae at top $3 \mathrm{ml}$ of tube. Error bar represents $\pm 1.0 \mathrm{SE}$. RE $82=$ positive control, pathogenic strain. RE 14 = negative control, non-pathogenic isolate. *: strains considered non-pathogenic. ATCC: American Type Culture Collection

peared frequently in otherwise healthy lots of oyster larvae and survived bacterial challenges better than other larvae.

\section{Conical tube assay}

The 3 isolates (RE 22, RE 98, RE 101) that were most pathogenic in the tissue-culture plate assay also demonstrated pathogenic activity in the conical tube assay, with no larvae suspended in the upper $3 \mathrm{ml}$ of the water column after $48 \mathrm{~h}$ at 20 and $26^{\circ} \mathrm{C}$ (Fig. 3). As in the tissue culture plate assay, results were variable with RE 60, which had an average of $12.5 \pm 7.5$ larvae in the top $3 \mathrm{ml}$ of the conical tubes from the $20^{\circ} \mathrm{C}$ trials after $24 \mathrm{~h}$, and no pathogenicity at $26^{\circ} \mathrm{C}$. In conical tubes where less than 20 larvae were present in the top $3 \mathrm{ml}$, few larvae were suspended throughout the water column. For some isolates (RE 19, RE 78), more larvae were observed in the top $3 \mathrm{ml}$ of the tubes after $48 \mathrm{~h}$ than after $24 \mathrm{~h}$. Most strains used in challenges in which over 20 larvae were suspended in the top $3 \mathrm{ml}$ of water, and had larvae dispersed throughout the water column, showed no pathogenicity after $48 \mathrm{~h}$.

$$
\mathrm{LD}_{50} \text { assay }
$$

The 3 highly pathogenic isolates (RE 22, RE 98, RE 101) demonstrated similar $\mathrm{LD}_{50}$ values (Table 2). These isolates killed similar ( $p>0.05$ ) amounts of oyster larvae at initial bacterial concentrations of $4.4 \pm 0.9 \times 10^{3}, 4.4 \pm 0.9 \times 10^{4}$, and $4.4 \pm 0.9 \times 10^{5} \mathrm{CFU} \mathrm{ml}^{-1}$ after $48 \mathrm{~h}$ (Fig. 4). Isolate RE 60 was a weaker pathogen and did not kill larvae in the $\mathrm{LD}_{50}$ assay within $48 \mathrm{~h}$. However, this bacterium killed $100 \%$ of the larvae at the highest concentration of $3.5 \times 10^{5} \mathrm{CFU} \mathrm{ml}^{-1}$ after $72 \mathrm{~h}$. After $72 \mathrm{~h}$ the larvae in the non-inoculated control conical tubes and the larvae inoculated with the non-pathogenic strain (RE 14) were still alive and swimming. Therefore, RE 60 was described as mildly pathogenic.

\section{Extracellular toxin production}

The presence of an extracellular toxin was examined by growing the strains RE 22, RE 98, and RE 101 in the presence of oyster larvae and collecting the culture filtrate. Results were similar for all 3 pathogenic strains tested in this experiment. After $24 \mathrm{~h}$, all larvae incubated with the $10 \%$ filtrate were alive and motile (Fig. 5). In the culture plates with $100 \%$ filtrate from the 3 pathogenic strains (RE 22, RE 98, RE 101), all larvae were alive, but only a few larvae were swimming. After $48 \mathrm{~h}$, all of the larvae were still swimming in the $10 \%$ solution of filtrate. Survival of larvae in the $100 \%$ filtrate solution was between 85 and $95 \%$. However, most of the larvae in the $100 \%$ filtrate had deformed vela and were not swimming.

\section{Phenotypic properties of isolates}

All 4 isolates tested (RE 22, RE 60, RE 98, and RE 101) and reference strains (Vibrio alginolyticus ATCC 19108, V. tubiashii ATCC 19106, V. alginolyticus ATCC 17749, V. splendidus ATCC 33125, and V. parahaemolyticus ATCC 17802) were Gram-negative, oxidase-positive, catalase-positive, motile rods (Table 2). All isolates grew well on TCBS agar at $20^{\circ} \mathrm{C}$. The 

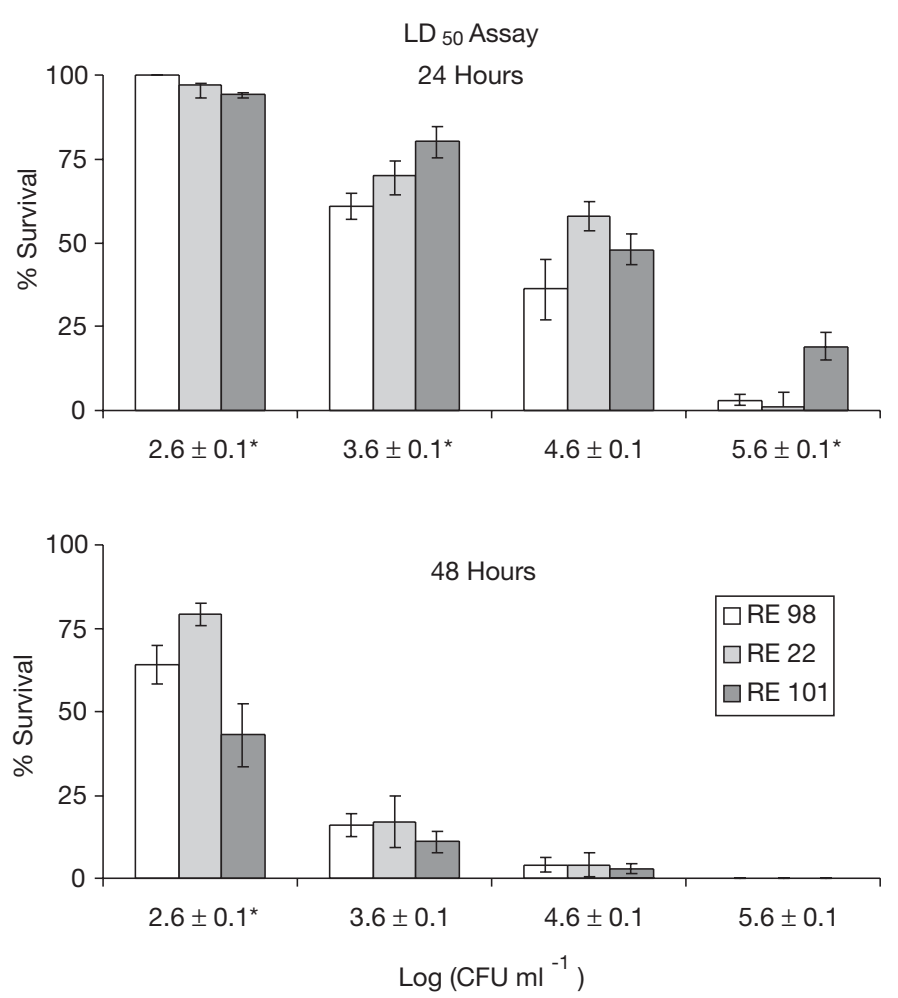

Fig. 4. Lethal dose $\left(\mathrm{LD}_{50}\right)$ assay of bacterial isolates RE 22, RE 98, RE 101 to Crassostrea gigas in tissue culture plates at $20^{\circ} \mathrm{C}$. No bars are present for the isolates with $0 \%$ survival of larvae. Error bar represents $\pm 1.0 \mathrm{SE}$. ${ }^{*}$ : significant difference $(\mathrm{p}<0.05)$ in percent survival among bacterial isolates at each concentration of inoculum. CFU: colony forming units

mildly pathogenic strain (RE 60) produced green colonies on TCBS agar (sucrose-negative) and pink colonies on Marine 2216 agar. The 3 pathogenic isolates and reference strains produced cream-colored colonies on Marine 2216 agar and yellow (sucrose-positive) colonies on TCBS agar.

All isolates and reference strains grew at 15, 20, and $30^{\circ} \mathrm{C}$. The 3 pathogenic isolates and reference strains also grew at $35^{\circ} \mathrm{C}$. None of the isolates or reference strains grew at $40^{\circ} \mathrm{C}$.

All of the isolates and reference strains grew at 3 and $6 \%$ salinity. Isolate RE 60 was resistant to both 10 and $150 \mu \mathrm{g}$ of the vibriostatic agent O/129. The other isolates were sensitive only to $150 \mu \mathrm{g}$ of O/129. Based on the phenotypic properties described, the 4 isolates were tentatively identified as members of the genus Vibrio (Holt et al. 1994).

\section{DISCUSSION}

Two methods were developed to quantify the pathogenicity of bacterial isolates to Pacific oyster larvae: a tissue-culture plate assay and a conical tube assay. In

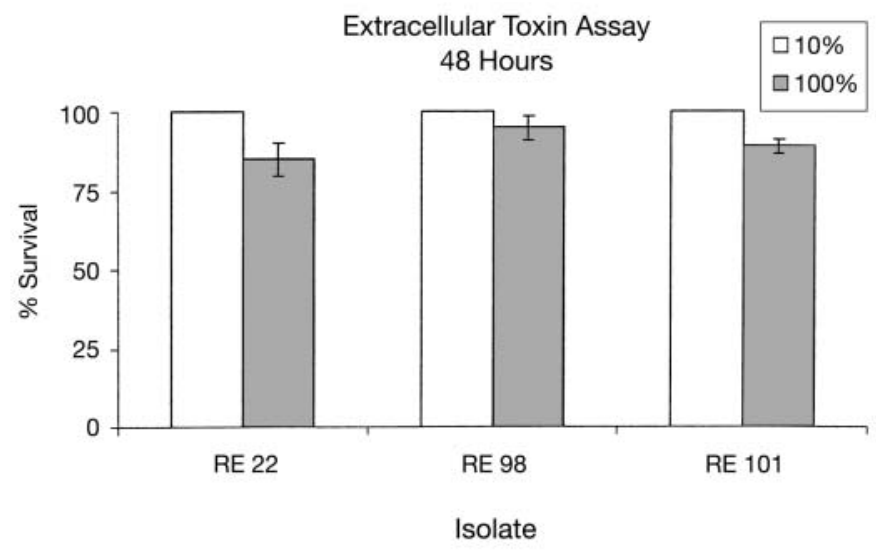

Fig. 5. Crassostrea gigas. Survival of Pacific oyster larvae in 2 concentrations of culture filtrate $(0.22 \mu \mathrm{m})$ after $48 \mathrm{~h}$ at $20^{\circ} \mathrm{C}$. No mortality observed at $24 \mathrm{~h}$. Error bar represents $\pm 1.0 \mathrm{SE}$

the tissue-culture plate assay, the small volume in the individual culture wells allowed for rapid preparation of the pathogenicity tests with replication. With this method, a large number of isolates were examined and efficiently screened. Mortality and motility of the larvae in the tissue culture plate wells were easily observed with a dissecting microscope without any further manipulation of the cultures, which likely reduced accidental contamination. Similarly, Sugumar et al. (1998) performed pathogenicity tests of Vibrio strains to Pacific oyster larvae in 6-well tissue culture plates with $10 \mathrm{ml}$ of filter sterilized seawater.

The conical tube assay clearly identified highly pathogenic bacteria, as dead larvae collected at the bottom of the tube. However, the tube assay was less reliable when mildly pathogenic strains were examined because larvae in these tubes dispersed throughout the tube within $48 \mathrm{~h}$. Therefore, it was important not to consider strains as pathogenic until the larvae were no longer swimming. The conical tube assay may be most useful for screening highly pathogenic strains.

The assays described in this study were first performed at $20^{\circ} \mathrm{C}$, the temperature previously used for pathogenicity testing of larval scallops (Riquelme et al. 1996) and larval Pacific oysters (Nottage \& Birbeck 1986, Riquelme et al. 1996, Gibson et al. 1998). Other pathogenicity experiments were performed on larval Pacific oysters (Jeffries 1982) and larval hard clams and eastern oysters (Tubiash et al. 1965) at temperatures as high as 27 to $28^{\circ} \mathrm{C}$. Pacific oyster larvae are reared in Pacific Northwest hatcheries at temperatures between 26 and $28^{\circ} \mathrm{C}$ (D. Thompson pers. comm.). Therefore, the tissue-culture plate and conical tube assays were repeated at $26^{\circ} \mathrm{C}$. Since there was little difference in the results for pathogenicity tests conducted at either temperature, the $\mathrm{LD}_{50}$ and extracellular toxin production assays were performed at $20^{\circ} \mathrm{C}$. 
$\mathrm{LD}_{50}$ assays are often used as a standard measure of pathogenicity. Determining the $\mathrm{LD}_{50}$ of larval pathogenic bacteria is labor-intensive and time-consuming. Thus, working with a small volume provides a consistent and efficient $\mathrm{LD}_{50}$ assay, as illustrated in the experiments described herein. The virulence of a large number of isolates was easily compared using the small, $4 \mathrm{ml}$ assay in tissue culture plates.

We identified 3 highly pathogenic strains (RE 22, RE 98, RE 101) and 1 mildly pathogenic strain (RE 60) of bacteria in the pathogenicity assay experiments performed with Pacific oyster larvae at 20 and $26^{\circ} \mathrm{C}$. The 3 highly pathogenic strains came from the same shellfish hatchery from 2 different years, while RE 60 originated from a different location. All 4 isolates were tentatively classified as members of the genus Vibrio.

As larvae exposed to the bacteria filtrates from RE 22, RE 98, and RE 101 larvae ceased swimming, the presence of a ciliostatic exotoxin was suspected. Toxin production has been previously demonstrated as a virulence mechanism of members of the Vibrio genus. Nottage \& Birbeck (1986) described a heat-stable ciliostatic toxin, a lethal protein, proteinase, and a haemolysin present in Vibrio culture supernatants that were tested against European and Pacific oyster spat. In the research described herein, the route of infection or type of toxin produced was not determined and would require additional investigation.

The presence of abnormal oyster larvae with deformed, stalk-like vela and circular swimming motion may be a good indicator of pathogenicity, as such larvae usually died within $24 \mathrm{~h}$ of the appearance of these signs. Tubiash et al. (1965) observed that malformed larvae were the last to show signs of Vibrio infection, and suggested the possibility that since the malformed larvae rarely feed, the initial bacterial invasion may occur through the alimentary tract. Elston \& Leibovitz (1980) confirmed the infection route of Vibrio through the alimentary tracts, but emphasized that this was one of several possible infection patterns. Invasion of bacteria along the outer shell surface and into the shell cavity was later shown to be the most common pattern of invasive infection (Elston 1999). Although not specifically enumerated in our pathogenicity assays, malformed larvae that looked like detached vela and in which no evidence of an oral cavity was observed (Fig. 2d) seemed to survive longer after infections with pathogenic bacteria. Therefore, integrity of the digestive tract may be an important requirement for the pathogenicity of the bacteria examined in our research, and this warrants further investigation.

Acknowledgements. This research was supported, in part, by a grant from the Washington Sea Grant Program (grant number NA16RG1044, project R/A-82) and the Saltonstall-
Kennedy Program of the National Marine Fisheries Service, NOAA, US Department of Commerce (grant number NA96FD0280) to the Pacific Shellfish Institute. Additional support was provided by the Egvedt Fellowship from the School of Aquatic and Fishery Sciences, University of Washington.

\section{LITERATURE CITED}

Brown C (1973) The effects of some selected bacteria on embryos and larvae of the American oyster, Crassostrea virginica. J Invertebr Pathol 21:215-223

Brown C (1981) A study of two shellfish-pathogenic Vibrio strains isolated from a Long Island hatchery during a recent outbreak of disease. J Shellfish Res 1:83-87

Elston RA (1984) Prevention and management of infectious diseases in intensive mollusc husbandry. J World Mariculture Soc 15:284-300

Elston RA (1999) Health management, development and histology of seed oysters. World Aquaculture Society, Baton Rouge

Elston RA, Leibovitz L (1980) Pathogenesis of experimental vibriosis in larval American oysters. Can J Fish Aquat Sci 37:964-978

Elston RA, Leibovitz L, Relyea D, Zatila J (1981) Diagnosis of vibriosis in a commercial oyster hatchery epizootic: diagnostic tools and management features. Aquaculture 24: 53-62

Gerhardt P, Murray RGE, Wood WA, Krieg NR (1994) Methods for general and molecular bacteriology. American Society for Microbiology, Washington, DC

Gibson LF, Woodworth J, George AM (1998) Probiotic activity of Aeromonas media on the Pacific oyster, Crassostrea gigas, when challenged with Vibrio tubiashii. Aquaculture 169:111-120

Holt JG, Krieg NR, Sneath PH, Staley JT, Williams ST (1994) Bergy's manual of determinative bacteriology. Williams \& Wilkins, Baltimore

Jeffries VE (1982) Three Vibrio strains pathogenic to larvae of Crassostrea gigas and Ostrea edulis. Aquaculture 19: 201-226

Lodeiros C, Bolinches J, Dopazo C, Toranzo A (1987) Bacillary necrosis in hatcheries of Ostrea edulis in Spain. Aquaculture 65:15-29

Manafi M, Kneifel W (1990) Rapid methods for differentiating Gram-positive from Gram-negative aerobic and facultative anaerobic bacteria. J Appl Bacteriol 69:822-827

Nottage AS, Birbeck TH (1986) Toxicity to marine bivalves of culture supernatant fluids of the bivalve-pathogenic Vibrio strain NCMB 1338 and other marine Vibrios. J Fish Dis 9:249-256

Reed LJ, Muench H (1938) A simple method of estimating fifty percent endpoints. Am J Hyg 27:493-497

Riquelme C, Toranzo A, Barja J, Vergara N, Araya R (1996) Association of Aeromonas hydrophila and Vibrio alginolyticus with larval mortalities of scallop (Argopecten purpuratus). J Invertebr Pathol 67:213-218

Sugumar G, Nakai T, Hirata Y, Matsubara D, Muroga K (1998) Vibrio splendidus biovar II as the causative agent of bacillary necrosis of Japanese oyster Crassostrea gigas larvae. Dis Aquat Org 33:111-118

Tubiash HS, Chanley PE, Leifson E (1965) Bacillary necrosis, a disease of larval and juvenile bivalve mollusks. J Bacteriol 90:1036-1044

Tubiash HS, Colwell RR, Sakazaki R (1970) Marine vibrios associated with bacillary necrosis, a disease of larval and juvenile bivalve mollusks. J Bacteriol 103:272-273 